\title{
Shtisel. Season 3. Directed by Alon Zingman. Written by Ori Elon and Yehonathan Indursky. NMC United Entertainment, [2013-]. Hebrew with English subtitles.
}

\section{Reviewed by Batya Weinbaum, American Public University System, USA.}

\section{The Women of Shtisel and Where They Live: Round Three}

The popular Harerdi drama written in overlapping episodic stories by Ori Elon and Yehonatan Indusrky and set in Geula, a religious neighborhood of Jerusalem, aired a bewitching nine-session third season on Netflix March 25, 2021, having already aired in Israel. The 2021 show begins four years after Season 2 ended. Each episode is 53-minute and is as deeply soul-touching and cathartic as good therapy for involved viewing communities.

As other viewers have noted, one persistent theme is grief over loss. Some characters die and others lose businesses, children, engagement partners, husbands, jobs, and their mental health. The characters, care for each other. Viewers can feel uncared for in comparison, unless remembering this is a tv show and perhaps a romanticization of the depth of caring that goes on in religious community life.

Nonetheless, for secular Jews (and others) in America, streaming this gem of epic folk story telling produced by Yes Studios provided an effortless if unorthodox way to return to Jerusalem this year for Pesach, rather than putting off the return to next year, an oath taken at Seders universally by those in Diaspora. If one has ever been to Jerusalem, the cinematography of the city simply transports you there. The curvy streets, the walls plastered with layers of posters printed in Hebrew, black coats walking by, reflections of brightly lit stores off the sides of white vans that go whizzing by.

Except for one, the focus of most initial reviews remains largely on the male protagonists and the anchoring relationship of father and son, Shulem and Akiva Shtisel. Yet for those who have undertaken organizing women's Seders as Passover events, many female characters leap out of the drama to make themselves known to help realize such a project.

\footnotetext{
Women in Judaism: A Multidisciplinary Journal Volume 17 Number 2 (2020) ISSN 1209-9392 (C) 2021 Women in Judaism, Inc.
}

All material in the journal is subject to copyright; copyright is held by the journal except where otherwise indicated. There is to be no reproduction or distribution of contents by any means without prior permission. Contents do not necessarily reflect the views of the editors. 
There is Ruchmani, played by Shira Haas who starred in Unorthodox between the end of Season 2 and this. Here rather than leave the community as the character she played did in the other show, the character she plays here puts herself at risk by bearing a child in spite of being warned of severe health risks, and while pregnant, takes on a job as a mail carrier to enable her husband to continue his Torah studies (the yeshiva he attends goes broke and slashes subsidies). She brings her father Lippe to his knees in the parking lot of the hospital where she is birthing. He jumps out of his van since he can't find a parking spot, impulsively praying in the headlights of an oncoming vehicle that he will repent if God spares her life and instead take his own. She also inspires her husband to invest in an apartment by writing letters to her child which he discovers. Since she has been told she might die in childbirth, she has dictated letters into a tape recorder that can be played to her child at different birthdays at certain milestones throughout life. She convinces him to go seek rabbinical permission to go against the Torah's frown on surrogacy, so intense is her desire to do more than pray to produce a child.

There is the matchmaker, wearing multiple layers of white pearls, who declines to take a whole plate in exchange for her services because she does not eat like she used to but suggests she will take a half plate instead. She works, she may be a widow, but she works she doesn't just sit around she says, after walking in on a restaurant kitchen and taking the cigarette out of Lippe the husband's mouth on her way in, explaining he must wait to hear the news and go out for the smoke later, and about herself, "Did you think I was just sitting around? By the way I work even when I sit around..." How many girls has the son met, she wants to know? The husband answers, none. I wasn't asking you. She takes the plate and goes to sit down to eat. She will speak only to Giti, Lippe's wife.

Yes, there is Giti, who holds the upper hand in the match situation. She also solves her husband's hairbrained scheme that turned into a problem on his job by recruiting bearded hippies off Jerusalem's Walking Street when he could not recruit extras for a movie set from his own community of ultra-Orthodox to play themselves, or other Haredim.

There is the wife of one of Shtisel's sons who gets her driver's license behind her husband's back. She buys herself a car against his will, saying she is the breadwinner, and she is the one who 
schleps to the school and to shop on the bus. Her argument: since she earns the bread, she will decide how to spend the cash too. As one reviewer refers to the scene:

In a politically charged vignette, one of the Shtisel balabustas (a Yiddish expression describing a good homemaker) relies on her impressive strength and wit to overcome the patriarchal conviction that women should not drive, ensuring that in the end-mini spoiler alert—she wins the peppy neon-green Fiat of her dreams. (Secunda) (definition added)

There is also Racheli, the art collector for a wealthy family trust who proposes to Shtisel's son Akiva in a hurry in order to rescue his daughter from "the Zionists" who had seized her (e.g., the welfare agency that had been responding to legitimate complaints) — accentuating the historic tension between the Haredim and the secular state that hosts them. But- the home visit had been provoked by Akiva showing up drunk at the day car to retrieve his child after having sent another drunk friend who had picked up the wrong one. And Shtisel's brother had tried to jump off the balcony to try to off himself out of despair during the home visit itself. But did that matter? All "the Zionists" needed to know was that all would be amended in the future, by a rich woman's touch. Even for them, a marriage certificate was good enough.

Then there is Shira, who takes long walks in the forest to assuage her fears, the woman university student studying flies. When asked on her arranged date to share something about herself, she says she loves to travel. "Do you mean like family trips on family weekends?" "That too. But I meant I love to travel by myself." "Aren't you afraid?" "On the contrary." She wins the heart of a young man, Yosa'le, who mistakenly took her for another Shira he was supposed to meet on an arranged date the matchmaker had set up. But he finds this one courageous.

There is the woman who shows up at Giti's restaurant when the woman's husband ran off and left her. She says, no, she has no idea what she is going to do, but she does not want him back, she wants a divorce, which she gets, having suggested at one point, Giti might want one too.

There is Libbi, the dead wife of Shtisel's son Kive (Akiva). She tells him she wishes she could still breastfeed as he tries to paint her from memory. And she persistently appears in the picture as he tries to paint Racheli his second wife as well, who tries to take him to Florida with tickets to an exhibition to get away from all this.

\footnotetext{
Women in Judaism: A Multidisciplinary Journal Volume 17 Number 2 (2020) ISSN 1209-9392 (C) 2021 Women in Judaism, Inc.
}

All material in the journal is subject to copyright; copyright is held by the journal except where otherwise indicated. There is to be no reproduction or distribution of contents by any means without prior permission. Contents do not necessarily reflect the views of the editors. 


\section{TV Review}

There is a woman who won three million in a lottery who decides to give it all to Shtisel to run his school.

\section{As Karen Skinazi wrote,}

the most remarkable part of Shtisel is its strong, capable women who are never simply relegated to the kitchen or the nursery. If you've watched the trailer, you've seen Giti making the rules of the house and Kive pushing a pram. Shtisel takes viewers' long-standing preconceptions about Charedi gender norms and turns them on their heads. So — start your rewatch!

The mode is not realism in more ways than one, the romanticism already mentioned. From the first episode to the last, dead people such as Libbi, Akiva's first wife, are shot as if they are real. No, she is not really speaking to tell Akiva that he should sell his paintings of her, to pay the rent, because she is dead. No, the table in the last scene that looks like it is peopled with many at the last feast before Akiva and Shtisel's brother leave Shulem's home is actually besides the three men, quite bare. And Akiva did not go to pick up his paintings to find them burning on the street, that was a dream. Nor did Ruchmani live through an earthquake. That was a dream too.

Yet forgiveness goes out to Yes as they have created a dreamlike fantasy where the characters care about each other, and where love is so deep that some will even bury their pride and lie or keep secrets or amend their own beliefs or even push their own beliefs aside to save not their own pride, but the pride of people they love. The need for tenderness they have tapped runs so deep. Thanks so much for creating a world in which women such as this can unfold, even if a bit precariously. It's for the world of the love that Facebook watch groups keep on watching mesmerizing, and growing.

\section{Works Cited}

Kustaowitz, Esther. "Long-awaited Shtisel Season 3 Brings More Faith, Grief, Family to Its Global Fan Base.”24 Mar 2021. The Jewish News of Northern California, https://www.jweekly.com/2021/03/24/long-awaited-shtisel-season-3-brings-more-faith-grieffamily-to-its-global-fan-base/. Accessed 31 Mar 2021.

Nathan, John. “TV Review: Shtisel.” The JC Reporter 26 Mar 20211 17:01. https://www.thejc.com/culture/tv/tv-review-shtisel-1.513634. Accessed 31 Mar 2021.

Women in Judaism: A Multidisciplinary Journal Volume 17 Number 2 (2020) ISSN 1209-9392

(C) 2021 Women in Judaism, Inc.

All material in the journal is subject to copyright; copyright is held by the journal except where otherwise indicated. There is to be no reproduction or distribution of contents by any means without prior permission. Contents do not necessarily reflect the views of the editors. 
Secunda, Shai. "A Season of Tzuris: The Shtisels Return.” 25 Mar 2021, Jewish Review of Books, Jewishreviewofbooks.com/contemporary-israel/10349/a-season-of-tsuris-the-shtiselsreturn/Accessed 31 Mar 2021.

Skinazil, Karen E H. "Sneak Peek at Shtisel \#3: All the Emotions and Kive's Got a Pram." 7 Jan 2021 08:03 https://www.thejc.com/culture/tv/sneak-peek-at-shtisel-3-all-the-emotions-and-kives-got-a-pram-1.510414 Accessed 31 Mar 2021.

Women in Judaism: A Multidisciplinary Journal Volume 17 Number 2 (2020) 